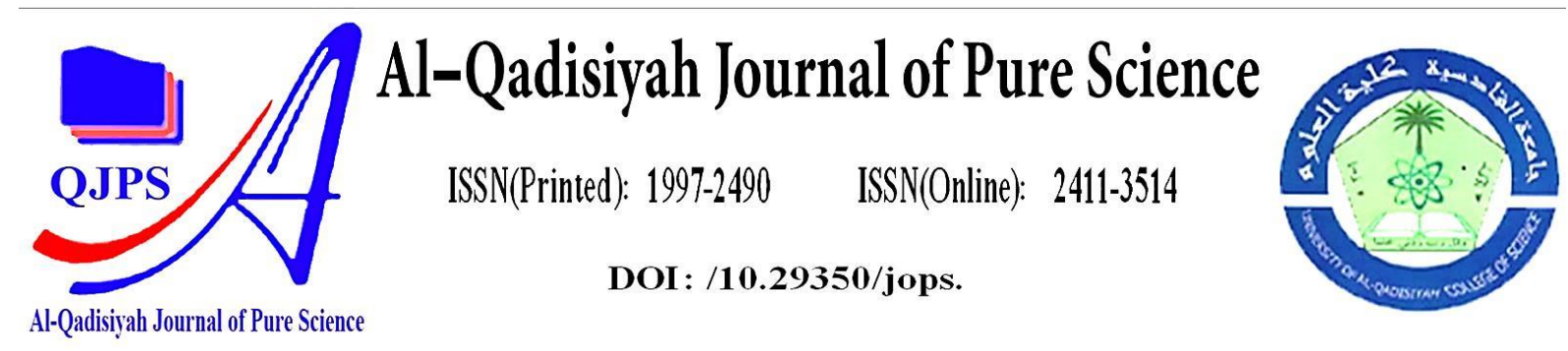

\title{
The Environmental Impact Assessment of the Spent Engine Oil Recycling Plant by using Leopold Matrix: Case Study Recycling Plant in Al-Diwaniyah City - Iraq
}

\section{Authors Names \\ a. Mukhtar D. Abbas \\ b. Mohammed K. Al kasser}

\section{Article History}

Received on: 23/6/2021

Revised on:22/7/2021

Accepted on:25/7/2021

\section{Keywords:}

Environmental Assessment, Environmental Impact, Leopold matrix ,Recycling.

DOI: https://doi.org/10.29350/ jops.2021.26. 4.1391

\begin{abstract}
The study achieve to make an environmental impact assessment for a spent engine oil recycling plant in AL-Diwaniyah city - Iraq. The assessment has been carried out using Leopold matrix. The studied plant deals with the bentonite clay as adsorbent material for removing the impurities from spent oil. The waste of bentonite clay which has been discharged as by- product waste without any minimal level of remediation which is harmful to the all environmental components in addition to that, the plant discharges air pollutants during the operation.

Leopold matrix is a simple method in terms of applying and using, it can be used easily for a comparison among different projects and gives clarified results. Moreover, the significant characteristic is its ability to covering biological, physical, economic and social environment.

From the results of Leopold matrix analysis, it can be observed that the maximum impact of the plant was on physical components in both quantity and importance, while there are some positive impacts on social components. Generally, all the impacts that caused from the plant is low on the environment by the comparison with maximum locally index of environmental impact value.
\end{abstract}

\section{Introduction}

Recycling process is defined as a collecting and manufacturing process of a spent materials for turning them into new products otherwise, they will be thrown away. Recycling process can be economical, social and environmental beneficial. The benefits of recycling process are conservation of the natural resources, saving energy, reducing the waste quantities, preventing the pollution and creating new jobs [10]. Therefore, the recycling process has been considered one of the environmental management principals and also it leads to sustainable development.

Establishment of projects and identifying specific sites for them has been conducted according to the national laws of environmental protection authority and to the Environmental Impact Assessment report (EIA), which identify and evaluate the significant environmental consequences of these projects [1]. On the other hand, the (EIA) is very important for implementing environmental management and principals of sustainable development [4]. In 
fact, it is an effective technique to predict and assess the adverse effects that result from different activities of projects on the chemical, physical, biological, ecological, cultural, social, and economic components of an environment. Having said that and according to the results of this assessment, the EIA offers solutions to mitigate and reduce the adverse effects[9].

There are many methods to identify the environmental impacts of projects such as checklists, quantitative methods, overlay maps, networks and matrices which include Leopold matrix [5], and rapid impact assessment matrix RIAM[7]. Some of these methods are simple and others are complex according to the required types of Data, Data formats, and different levels of expertise and technical advancement interpretation. Therefore, the using of any method depends on the type of project, activities involved in projects along with its size that are impacted by the environment and EIA evaluators[3].

This method has been developed by Leopold in the late 1960s of the last century. In which all environmental consequences of a project are considered and is approved by the American National Environmental Law [8]. This tool takes in consideration the harmful or the beneficial environmental impacts. Moreover, it shows each activity and its potential to generate an effect to environmental components. The matrix consist from a list of the project activities on the horizontal axis while the environmental factors listed on the vertical axis [2]. Thus, the interaction between these two items shows its magnitude and importance. The Leopold matrix also applied extensively in UNEP reports due to its simplicity to follow up. None the less, it can be used easily for a comparison among different projects and gives clarified results. Finally, the significant characteristic is its ability to covering biological, physical, economic and social environment. Therefore, Muslim et al [6] used Leopold Matrix to evaluate the air and water quality which damaged by industrial activities in the middle Euphrates regions of Iraq. So in this study, environmental impact assessment for a plant of spent engine oil recycling which is located in AL-Diwaniyah city has been carried out by using the Leopold matrix.

\section{Case Study}

The studied plant located in AL-Diwaniyah city with distance of seven kilometers east of the city municipality borders and two kilometers than the residential communities, between $\left(45^{\circ}\right.$ $02^{\prime} 44^{\prime \prime}$ East, $31^{\circ} 59^{\prime} 15^{\prime \prime}$ North) with area of $10000 \mathrm{~m}^{2}$, and it is neighboring to the international highway. Where the nature of land is unusable for cultivation and it is candidate as industrial region as well as the central solid waste dump of AL-Diwaniyah city one kilometer from the plant location Fig. 1.

The plant of the spent engine oil recycling uses the bentonite clay as an adsorbent material to remove the impurities from the spent engine oil. The process is accompanied by high temperature degree and pressure as well as adding materials to raise the viscosity of final product. The solid waste which has been produced from the purification process of spent oil is bentonite clay polluted with impurities of the spent oil, which is harmful to the environment since it contains petroleum components and is disposed without any minimal remediation in the solid waste dump. 


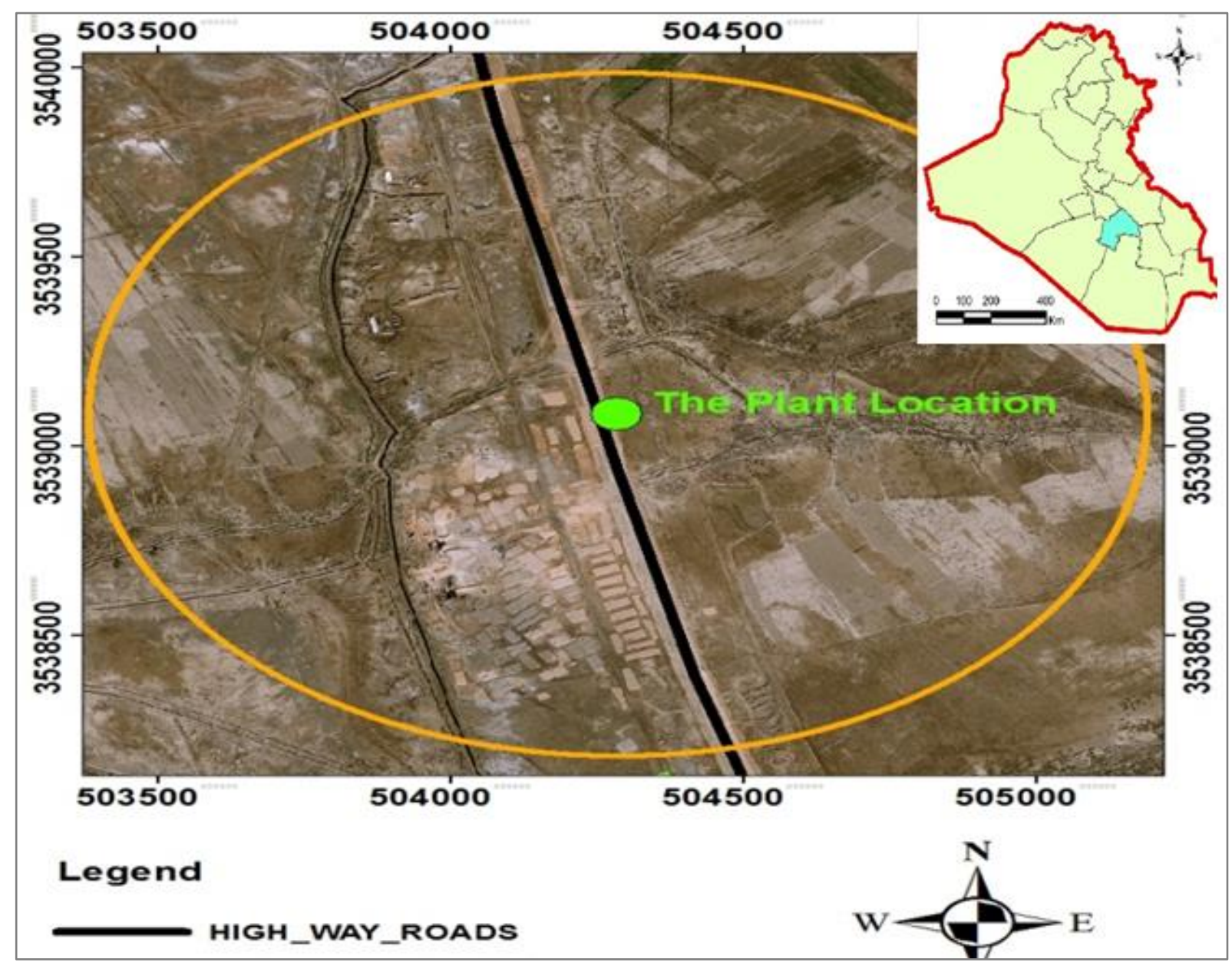

Fig. 1 The Plant Location And The Neighboring Region With Radius One Kilometer.

\section{Leopold Matrix Method}

This matrix consists of 100 activities and 88 environmental factors to form 8800 cells, each cell is diagonally bisected to show activity from horizontal axis and environmental factor from vertical axis. These matrices are formed for four environments: biological, physical, social and economic on the horizontal axis against the activities that occur in the project on the vertical axis[8]. In each cell there is a distinction between the value and importance of the impact on a scale of 1 - 10 [5].

In general, this matrix is applied in a reduced mode, which takes into account the actions applied in the project and the most relevant impacts only[2]. Moreover, each cell will contain a fraction where the numerator represents the magnitude of impact and the denominator its important, the sum of the columns will show the impact of the project actions on each environmental factor and its fragility, while the sum of the rows will show a relative assessment of the impact of each actions on the environment and its aggression. When multiplying the importance by the magnitude the obtained value is equal to the effect resulting from the action on the environmental parameter, this value can range from 1-50 and can either be negative or positive [5]. Table 1 explains the measurable values of the magnitude and importance of impact. 
Table 1 indices the magnitudes and importance of impact

\begin{tabular}{|c|c|c|c|c|}
\hline \multirow{2}{*}{ Magnitude Impact } & \multicolumn{2}{|c|}{ Index for magnitude impact } & \multirow{2}{*}{$\begin{array}{l}\text { Importance } \\
\text { impact }\end{array}$} & \multirow{2}{*}{$\begin{array}{c}\text { Index of Importance } \\
\text { impact }\end{array}$} \\
\hline & Negative impact & Positive impact & & \\
\hline Extremely high & -10 & 10 & \multirow{2}{*}{ Globally } & \multirow[b]{2}{*}{5} \\
\hline Very high & -9 & 9 & & \\
\hline Relative High & -8 & 8 & \multirow{2}{*}{ Nationally } & \multirow{2}{*}{4} \\
\hline High & -7 & 7 & & \\
\hline Above average & -6 & 6 & \multirow{2}{*}{ Regionally } & \multirow{2}{*}{3} \\
\hline Average & -5 & 5 & & \\
\hline Low & -4 & 4 & \multirow{2}{*}{ Locally } & \multirow{2}{*}{2} \\
\hline Very low & -3 & 3 & & \\
\hline Extremely low & -2 & 2 & \multirow{2}{*}{ No significant } & \multirow{2}{*}{1} \\
\hline No significant & -1 & 1 & & \\
\hline
\end{tabular}

\section{Environmental impacts calculation}

In the Leopold Matrix the impacts of spent engine oil recycling plant on the environmental physical, biological and social components are calculus by the flowing equation: [5]

$\mathrm{EIV}=\mathrm{M} \times \mathrm{I}$, Total EIV $=\sum \mathrm{M} \times \mathrm{I}$

Where,

$\mathrm{M}=$ magnitude, $\mathrm{I}=$ Importance, EIV = Environmental Impact Value

\section{Results and Discussion}

The a recycling plant for the spent engine oil has two opposite impacts on the physical and social components of environment, the positive impacts are obtained from recycling process principle of spent oil and the negative impacts that result from discharging of solid waste into the environment directly without any remediation. while the impacts on the biological components is a just negative. Tables 2, 3 and 4 identify the impacts of the plant on the environmental components.

Where the importance and magnitudes of impact evaluation is generally based on the value judgment and experience of the evaluators and visual observation during the field monitoring by the researchers. 
Table 2 interactions between the actions and physical impact factors

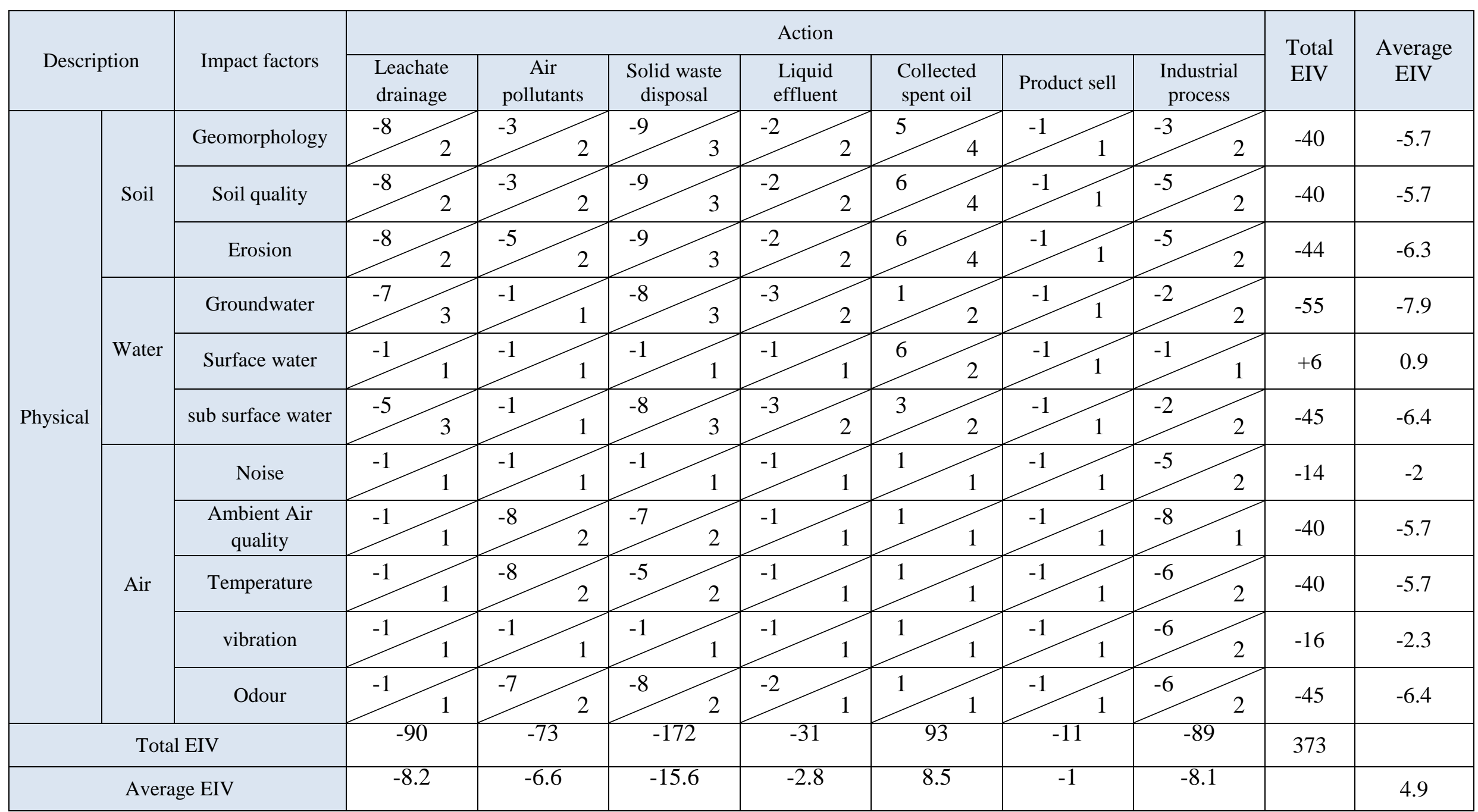


Table 3 interactions between actions and biological impact factors

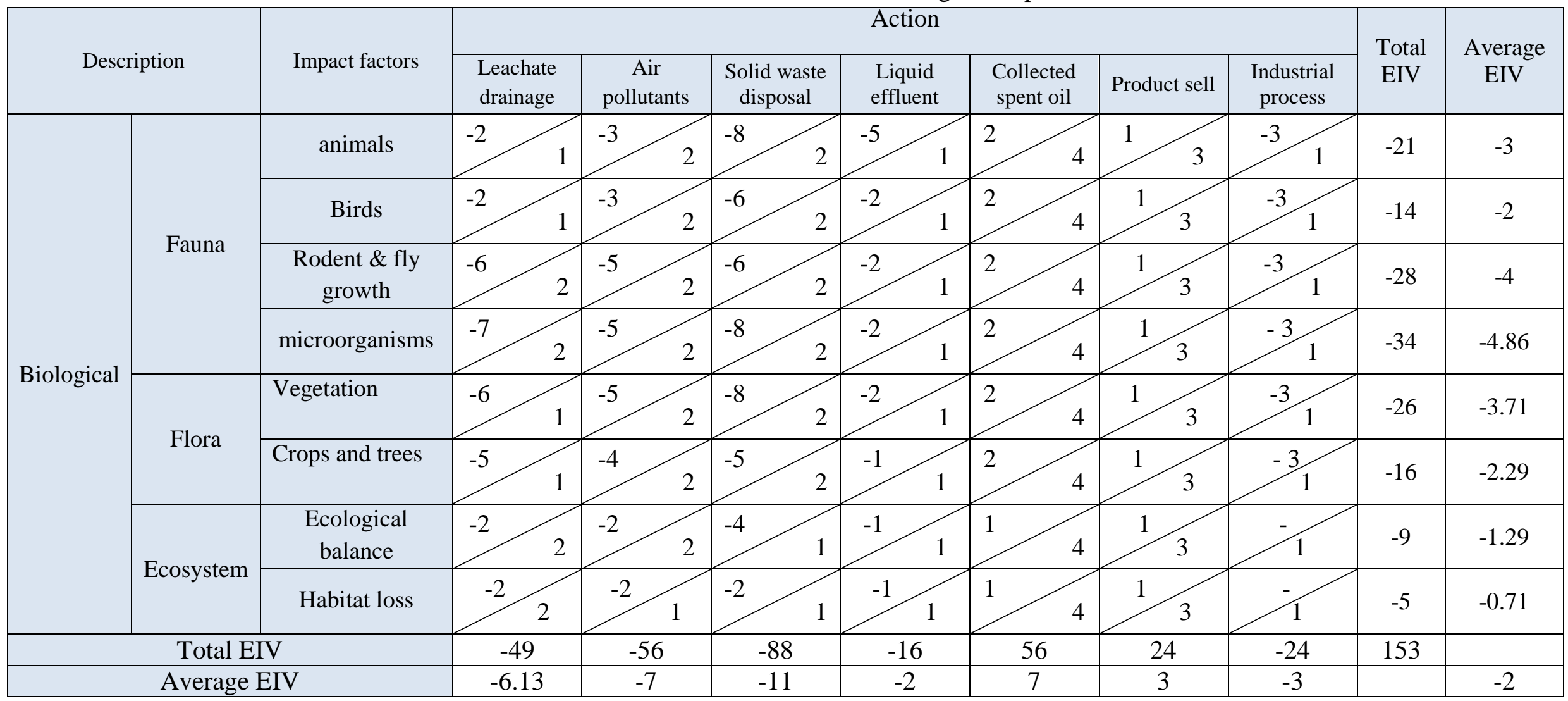


Table 4 interactions between actions and social impact factors

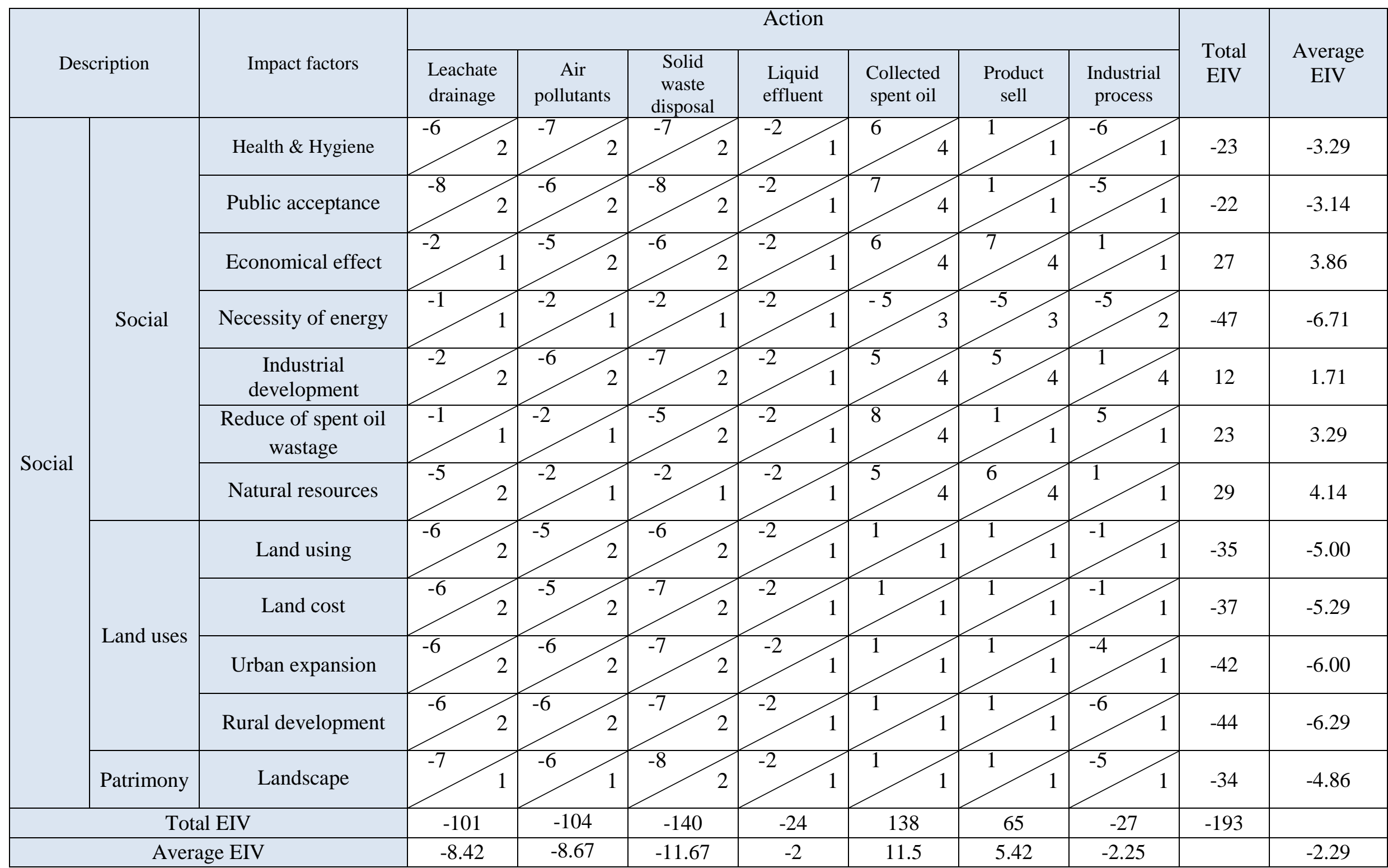


The above tables show the interaction between the industrial activities of plant and the environmental factors، where there are two types of impacts positive and negative due to the nature of action. Figures 2, 3 and 4 show the total environmental impacts values which obtained from the effect of the actions on the physical, biological and social impact factor respectively.

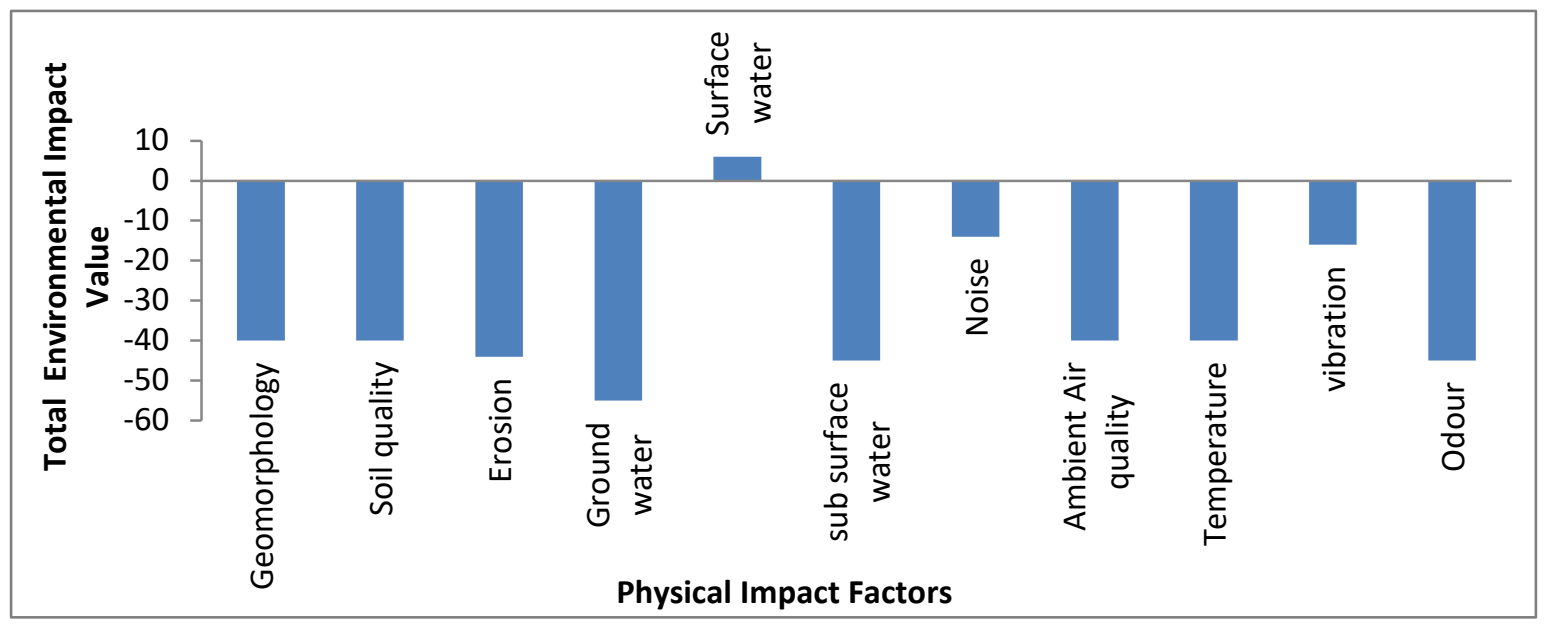

Fig. 2 the total impact value on the physical factors

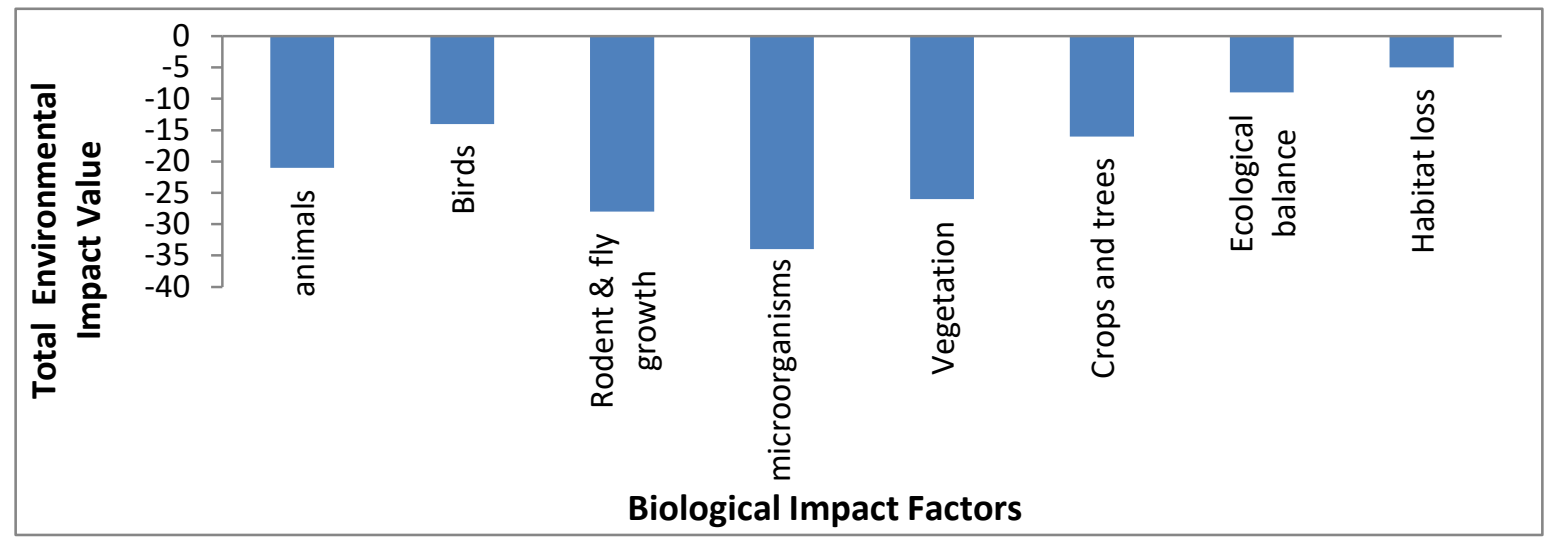

Fig. 3 the total impact value on the biological factors

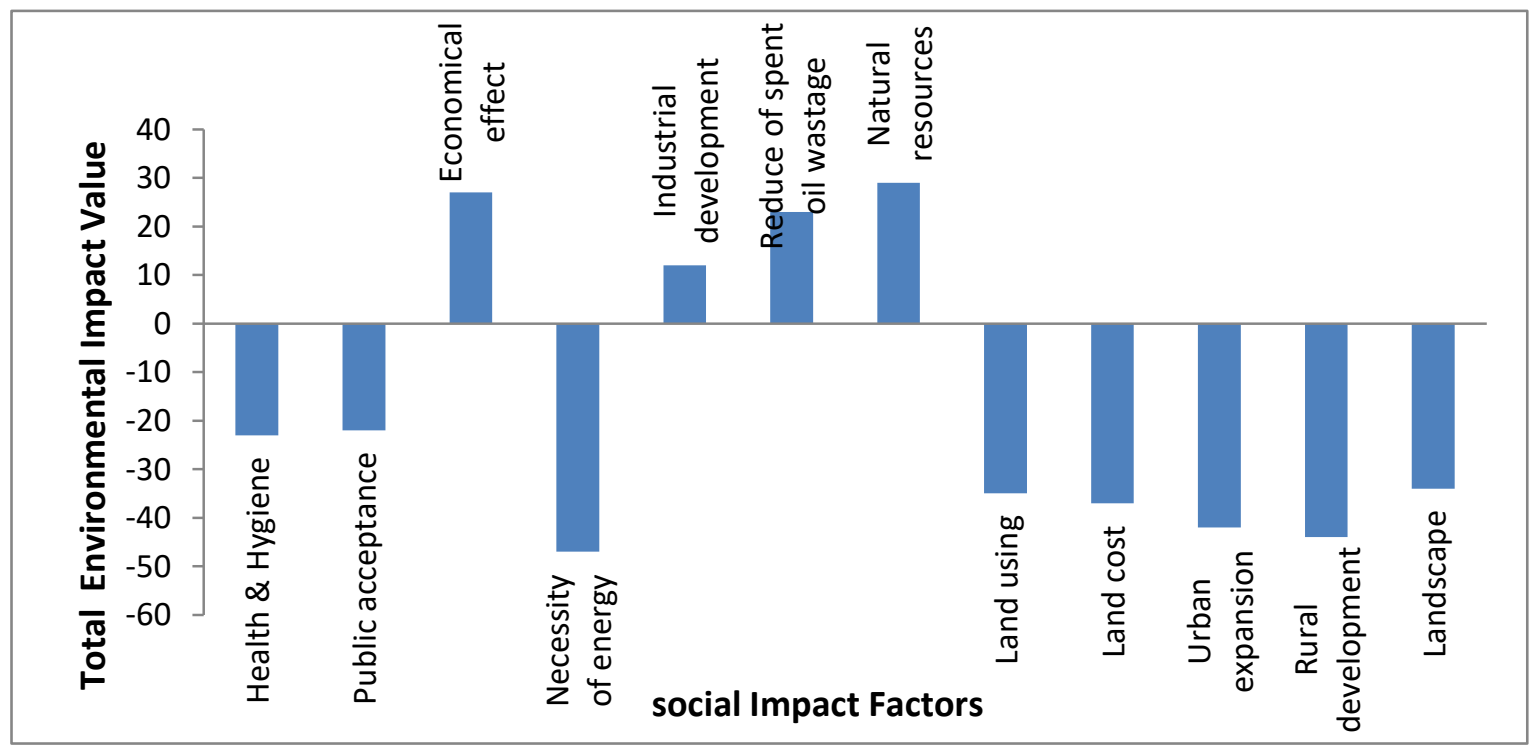

Fig. 4 the total impact value on the social factors 
The Leopold matrix method is of little value for evaluating impacts because there is no standardized way of assessing the scores, nor is there a means of assigning weight to different impacts to determine relative importance [6].

The impacts that result from plant's actions on the environmental physical, biological and social components are with different levels where there are positive impact on some of the physical and social impact factors while just negative impacts on the biological factors. The recycling process minimizes the waste quantities in environment and its reflections on the environment factors is positive impact as shown in the Fig. 2 with regard surface water.

According to the magnitude of impacts arrange from (-10 to 10), the EIVs arrange from 50 if globally impacts to 10 if the impacts are not significant regardless if positive or negative as shown in the Table 5.

Table 5 maximum and minimum of EIV of impact factors

\begin{tabular}{|c|c|c|c|c|c|}
\hline \multirow[b]{2}{*}{ Importance } & \multirow[b]{2}{*}{$\begin{array}{c}\text { Index } \\
\text { of importance }\end{array}$} & \multicolumn{2}{|c|}{ Positive effect } & \multicolumn{2}{|c|}{ Negative effect } \\
\hline & & $\begin{array}{l}\text { Maximum } \\
\text { of EIV }\end{array}$ & $\begin{array}{l}\text { Minimum } \\
\text { of EIV }\end{array}$ & $\begin{array}{l}\text { Maximum } \\
\text { of EIV }\end{array}$ & $\begin{array}{l}\text { Minimum } \\
\text { of EIV }\end{array}$ \\
\hline Globally & 5 & 50 & 5 & -50 & -5 \\
\hline Nationally & 4 & 40 & 4 & -40 & -4 \\
\hline Regionally & 3 & 30 & 3 & -30 & -3 \\
\hline Locally & 2 & 20 & 2 & -20 & -2 \\
\hline NO Significant & 1 & 10 & 1 & -10 & -1 \\
\hline
\end{tabular}

Depending on the Tables 2, 3 and 4, we observed most the levels of importance arranged from locally to no significant (2 to 1) while some of them arranged from nationally to regionally (4 to 3), therefore, we will consider the importance level of project is locally for assessment process and comparison as shown in the Fig. 5.

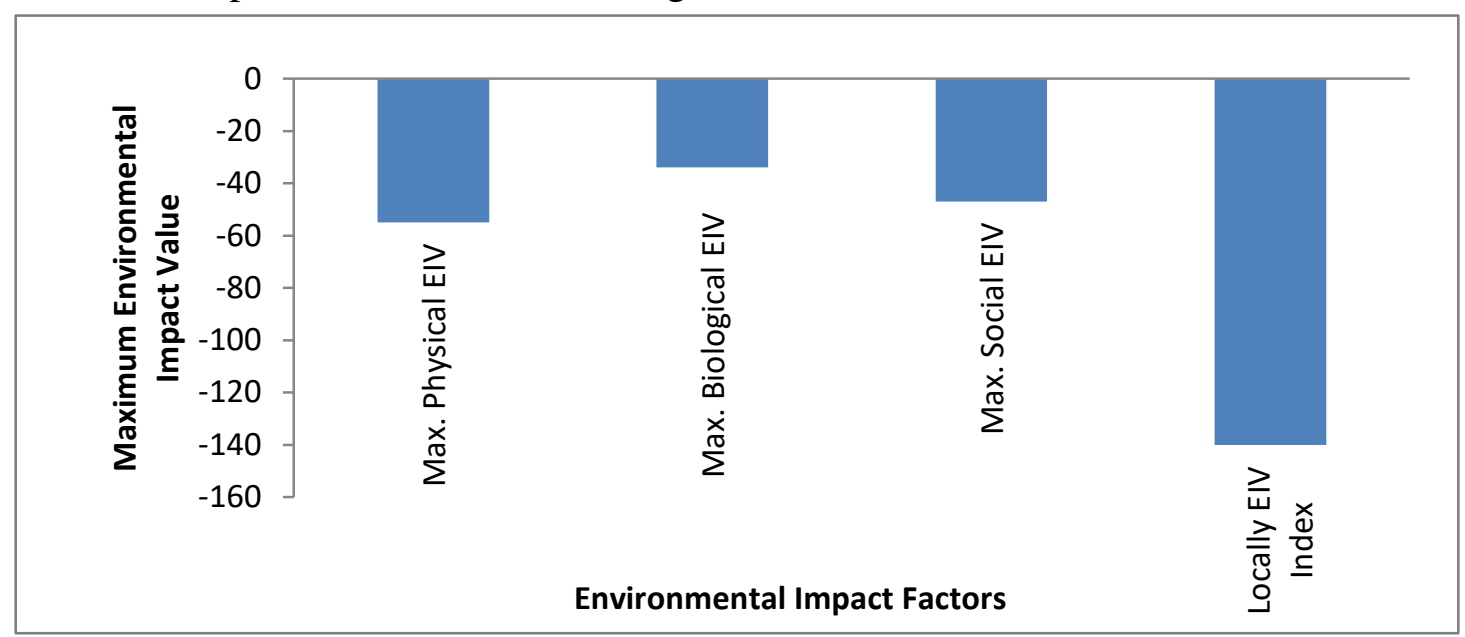

Fig. 5 Comparison between maximum EIV and maximum locally EIV index

\section{Conclusions}

1- The maximum impact of this project is on the physical components.

2- The positive effects of this project was on the social and then physical components result from the recycling process for spent engine oil.

3- All the impacts on the biological components are negative.

4- The final assessment of plant is excepted according to the results of EIVs. 


\section{References:}

[1] Al-Waqi'a Iraqi newspaper, No. 4225 (2012), "Environmental Determinants instructions of the projects establishment and monitoring the safety of their implementation No. (3) for the year 2011".

[2] Clark BD, Gilad A, Bisset R, Tomlinson P (2012) Perspectives on Environmental Impact Assessment: Proceedings of the Annual WHO Training Courses on Environmental Impact Assessment, Centre for Environmental Management and Planning Springer Science \& Business Media

[3] Karimi, H., Neamat, S., \&Galali, S. (2020). Application of Mathematical Matrices for Environmental Impact Assessment, A Case Study of Thermal Power Plant. Journal of Applied Science and Technology Trends, 1(1), 13-16.

[4] Kumar, K. S., Kumar, P. S., \& Babu, M. R. Application of RIAM to the Environmental Impact Assessment of a Proposed Municipal Solid Waste Disposal Project.

[5] Leopold B L B, Clarke F E, and Hanshaw B B, 1991, "A Procedure for Evaluating Environmental Impact", United States Department of the Interior, Washington.

[6] Muslem, M.A., J. Homod, H.M.Selman,2010. Environmental impact assessment and its application to the middle Euphrates region. Babylon University J. for Pure and Applied Science.Vol.18(2):724753.

[7] Pastakia, C.M.R., (1998). The rapid impact assessment matrix (RIAM) - a new tool for environmental impact assessment. In: Jensen, K. (Ed.), Environmental Impact Assessment Using the Rapid Impact Assessment Matrix (RIAM), Olsen \& Olsen, Fredensborg, Denmark.

[8] Sajjadi, S. A., Aliakbari, Z., Matlabi, M., Biglari, H., \& Rasouli, S. S. (2017).

Environmental impact assessment of Gonabad municipal waste landfill site using Leopold Matrix. Electronic physician, 9(2), 3714.

[9] Taheri, M., Gholamalifard, M., Ghazizade, M. J., \& Rahimoghli, S. (2014). Environmental impact assessment of municipal solid waste disposal site in Tabriz, Iran using rapid impact assessment matrix. Impact Assessment and Project Appraisal, 32(2), 162-169.

[10] United States Environmental Protection Agency, Recycling Basics,2020"Recycling Economic Information (REI) Report" 